
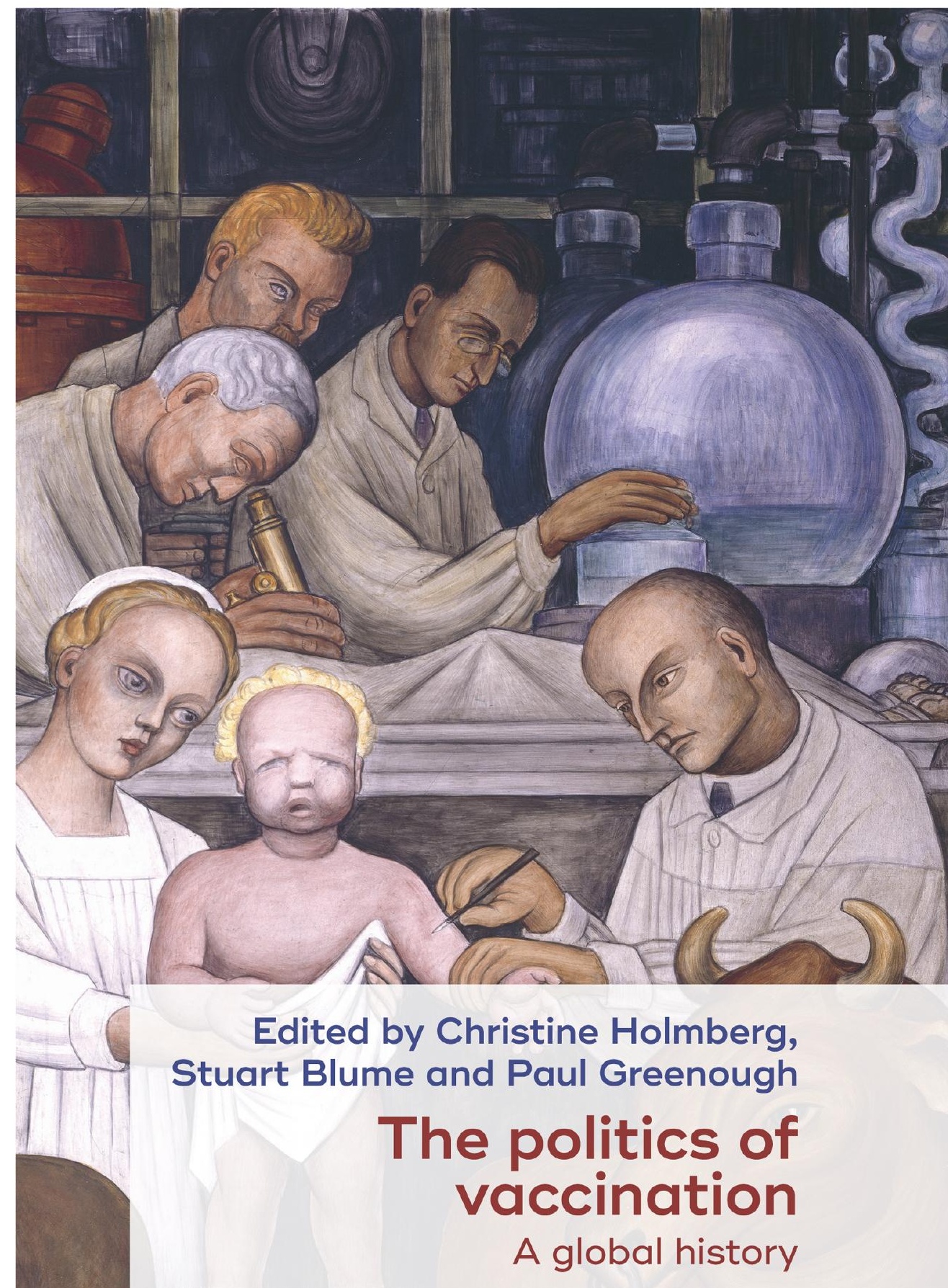

Edited by Christine Holmberg, Stuart Blume and Paul Greenough

\title{
The politics of vaccination
}

A global history

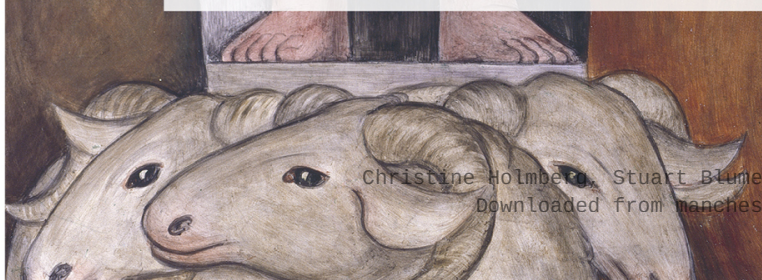




\section{The politics of vaccination}

\section{MANCHESTER \\ 1824}

Manchester University Press 


\section{SSH}

\section{SOCIAL HISTORIES OF MEDICINE}

Series editors: David Cantor and Keir Waddington

Social Histories of Medicine is concerned with all aspects of health, illness and medicine, from prehistory to the present, in every part of the world. The series covers the circumstances that promote health or illness, the ways in which people experience and explain such conditions and what, practically, they do about them. Practitioners of all approaches to health and healing come within its scope, as do their ideas, beliefs and practices, and the social, economic and cultural contexts in which they operate. Methodologically, the series welcomes relevant studies in social, economic, cultural and intellectual history, as well as approaches derived from other disciplines in the arts, sciences, social sciences and humanities. The series is a collaboration between Manchester University Press and the Society for the Social History of Medicine.

\section{Previously published}

The metamorphosis of autism: A history of child development in Britain Bonnie Evans

Payment and philanthropy in British healthcare, 1918-48 George Campbell Gosling 


\section{The politics of vaccination}

A global history

\section{Edited by Christine Holmberg, Stuart Blume and Paul Greenough}

Manchester University Press 
Copyright (C) Manchester University Press 2017

While copyright in the volume as a whole is vested in Manchester University Press, copyright in individual chapters belongs to their respective authors, and no chapter may be reproduced wholly or in part without the express permission in writing of both author and publisher.

Published by Manchester University Press

Altrincham Street, Manchester M1 7JA

www.manchesteruniversitypress.co.uk

British Library Cataloguing-in-Publication Data

A catalogue record for this book is available from the British Library

Library of Congress Cataloging-in-Publication Data applied for

ISBN 9781526110886 hardback

ISBN 9781526110909 paperback

First published 2017

The publisher has no responsibility for the persistence or accuracy of URLs for any external or third-party internet websites referred to in this book, and does not guarantee that any content on such websites is, or will remain, accurate or appropriate.

Typeset in 11 on 12 pt Arno Pro Regular by Toppan Best-set Premedia Limited 